\title{
Association between depressive symptoms and oral health care in non- institutionalized elders in Northeastern Brazil
}

Associação entre sintomas depressivos e cuidados com a saúde bucal em idosos não

institucionalizados no Nordeste do Brasil

Asociación entre sintomas depressivos y atención de salud bucal em ancianos no institucionalizados em el noreste de Brasil

Isis de Araújo Ferreira Muniz ORCID: https://orcid.org/0000-0002-5550-0294 Federal University of Paraiba, Brazil E-mail: isismuniz13@hotmail.com

Wellinton Silva Souto

ORCID: https://orcid.org/0000-0001-5437-6837 Federal University of Paraiba, Brazil E-mail: wellitonsouto@hotmail.com

Allan Jonattan de Lima Queiroz ORCID: https://orcid.org/0000-0002-6119-1715 Federal University of Paraiba, Brazil E-mail: ajlqueiroz@gmail.com

Carolinne Medeiros de Araújo Souza ORCID: https://orcid.org/0000-0001-7349-066X Federal University of Paraiba, Brazil E-mail: carol_medeiros4@hotmail.com

Clarissiane Serafim Cardoso ORCID: https://orcid.org/0000-0002-3922-965X Federal University of Paraiba, Brazil E-mail: clarissiane.serafim@gmail.com

Joyce Andreza Moreira Pessôa ORCID: https://orcid.org/0000-0003-0751-9107 Federal University of Paraiba, Brazil

E-mail: joyceandreza_cz@hotmail.com Sara Brito Silva Costa Cruz ORCID: https://orcid.org/0000-0003-1509-900X Federal University of Paraiba, Brazil E-mail: saradyas@hotmail.com

Paulo Rogério Ferreti Bonan ORCID: https://orcid.org/0000-0002-4449-4343 Federal University of Paraiba, Brazil E-mail: pbonan@yahoo.com

André Ulisses Dantas Batista

ORCID: https://orcid.org/0000-0003-1593-0174 Federal University of Paraiba, Brazil E-mail: andreulisses@yahoo.com.br

\begin{abstract}
This work aims to investigate the association between geriatric depression and oral self-perception, assessing functional scales, socioeconomic determinants, and normative oral conditions. The study was based on an inductive approach, with statistical procedures and descriptive technique using direct observation with 250 elders enrolled at the Reference Center, located in João Pessoa, Paraíba, Northeastern Brazil. Data collection was carried out focusing on a socioeconomic survey. A clinical examination was performed to obtain data on DMFT, edentulism, the need and use of prosthesis, and oral lesion. GOHAI, Pfeffer, Katz and Geriatric Depression Scales (GDS-15) were made. The elders were mostly illiterate women, from 60 to 70 years old, with low income. The average DMFT was 28.17, and edentulism was perceived in $55.2 \%$. Oral self-perception was unfavorable for $87.2 \%$, depressive symptoms affected $33.2 \%$ of individuals and functional dependence was noticed in 9.2\%. The Katz and Pfeffer scales were statistically associated with the GDS-15 scale $(\mathrm{p}<0.05)$. The depressive symptoms were associated with the female gender, illiterate condition, and poor food intake after binary regression. However, they are not associated with normative oral conditions and oral self-perception in non-institutionalized elders in Northeastern Brazil.
\end{abstract}


Keywords: Depression; Aged; Oral health.

\begin{abstract}
Resumo
Este trabalho tem como objetivo investigar a associação entre depressão geriátrica e autopercepção oral, avaliando escalas funcionais, determinantes socioeconômicos e condições orais normativas. O estudo baseou-se na abordagem indutiva, com procedimentos estatísticos e técnica descritiva por meio de observação direta com 250 idosos cadastrados no Centro de Referência, localizado em João Pessoa, Paraíba, Nordeste do Brasil. A coleta de dados foi realizada com foco em um levantamento socioeconômico. Foi realizado exame clínico para obtenção de dados sobre CPOD, edentulismo, necessidade e uso de prótese e lesão oral. GOHAI, Pfeffer, Katz e Escalas de Depressão Geriátrica (GDS15) foram feitas. Os idosos eram em sua maioria mulheres analfabetas, de 60 a 70 anos, com baixa renda. O CPOD médio foi de 28,17 e o edentulismo foi percebido em $55,2 \%$. A autopercepção oral foi desfavorável em $87,2 \%$, os sintomas depressivos atingiram $33,2 \%$ dos indivíduos e a dependência funcional foi observada em $9,2 \%$. As escalas de Katz e Pfeffer foram estatisticamente associadas à escala GDS-15 ( $<<0,05)$. Os sintomas depressivos foram associados ao sexo feminino, analfabetismo e má ingestão alimentar após regressão binária. No entanto, não estão associados a condições orais normativas e autopercepção oral em idosos não institucionalizados no Nordeste do Brasil.
\end{abstract}

Palavras-chave: Depressão; Idoso; Saúde bucal.

\title{
Resumen
}

Este trabajo tiene como objetivo investigar la asociación entre depresión geriátrica y autopercepción oral, evaluando escalas funcionales, determinantes socioeconómicos y condiciones orales normativas. El estudio se basó en un enfoque inductivo, con procedimientos estadísticos y técnica descriptiva mediante observación directa con 250 ancianos inscritos en el Centro de Referencia, ubicado en João Pessoa, Paraíba, noreste de Brasil. La recolección de datos se realizó enfocándose en una encuesta socioeconómica. Se realizó una exploración clínica para obtener datos sobre CPOD, edentulismo, necesidad y uso de prótesis y lesión bucal. Se elaboraron las escalas de depresión GOHAI, Pfeffer, Katz y geriátrica (GDS-15). Los ancianos eran en su mayoría mujeres analfabetas, de 60 a 70 años, de bajos ingresos. El CPOD promedio fue de 28,17 y se percibió edentulismo en el 55,2\%. La autopercepción oral fue desfavorable para el $87,2 \%$, los síntomas depresivos afectaron al 33,2\% de los individuos y se notó dependencia funcional en el 9,2\%. Las escalas de Katz y Pfeffer se asociaron estadísticamente con la escala GDS-15 ( $<<0,05)$. Los síntomas depresivos se asociaron con el sexo femenino, la condición de analfabetos y la ingesta deficiente de alimentos después de la regresión binaria. Sin embargo, no están asociados con condiciones orales normativas y autopercepción oral en ancianos no institucionalizados en el noreste de Brasil.

Palabras clave: Depresión; Anciano; Salud bucal.

\section{Introduction}

Depression is the most common psychiatric illness among the elderly and constitutes a significant and growing public health problem (Eulálio et al., 2015; Skośkiewicz-Malinowska et al., 2018). Late or geriatric depression, which begins after 60 years of age (Eschweiler, 2017), can affect a quarter of this target population (Forlani et al., 2014), with symptoms that include suicidal thoughts, mental/psychomotor retardation, sleep difficulties, and decreased appetite, and may affect directly the quality of life (Brennan \& Strauss, 2014; Bakker et al., 2018). Diagnosis in mental health and geriatric care with a multidisciplinary team is important to ensure integral health care for this population (Menezes-Silva et al., 2016; Halpern, 2020). Treating symptoms may reverse sequelae and/or stabilize decline, however, most older adults experience chronicity of depressive symptoms (Hybels et al., 2016).

Theoretically, cognitively debilitated and depressed individuals tend to present a more precarious state of oral health (Krausch-Hofmann et al., 2015), which is often related to lower dental self-care. Also, depressive symptoms may impair oral health by various biological pathways (Hybels et al., 2016) due to cellular aging and increased inflammatory activity (Révész et al., 2014). Studies indicate that adults and the elderly with diagnosed depression and anxiety have a higher risk of future tooth loss (Okoro et al., 2012; Persson et al., 2003). Besides, stress and depression may be associated with periodontal destruction by reducing the immune response (Warren et al., 2014). Xerogenic drugs, which this population tends to use, also significantly increase the risk of lower salivary flow, triggering several oral consequences, such as dental caries, periodontal disease, fungal infections, and taste disorders, which can seriously compromise speech, feeding, and swallowing of these patients (Ouanounou, 2016; Seo \& Kim, 2020). These findings become clinically important as low oral health also has other implications and adverse 
effects (Hybels et al., 2016). Individuals with periodontal disease may be at increased risk of chronic systemic inflammation, which can trigger cognitive, visual, and physical deterioration, leading to low intellectual activity (Tomioka et al., 2015; Choi et al., 2020).

Although the relation between depressive symptoms and the worst oral condition seems to be obvious, this fact was not supported by a recent study (Mendes et al., 2013). Nevertheless, the association between periodontal conditions and depression is not consensual and some authors affirm that the high susceptibility to depression does not play a significant role in the etiology and severity of periodontal disease (Kjellström et al., 2017). Another study showed that the parameters of depression were not associated with clinical insertion level $\geq 5 \mathrm{~mm}$ in the sample analyzed or even with missing teeth (Solis et al., 2014).

Depressive symptomatology in the elderly can be reliably assessed through the shorter validity version of the Geriatric Depression Scale (GDS-15) (Yesavage et al., 1983; Sheikh \& Yesavage, 1986). But, in fact, there is a limited understanding of how chronic depressive symptoms are related to oral health impairment in the elderly population (Hybels et al., 2016).

To date, no previous study has dealt with the association between oral normative conditions, oral lesions, functional scales, socioeconomic determinants, oral self-perception, and depressive symptoms as a dependent variable in an elderly population. In this way, in addition to trying to fill this gap in the literature, the objective of this study was to investigate the presence or absence of association between depressive symptoms and the variables mentioned above in a community of noninstitutionalized elderly people in Northeast Brazil. The working hypothesis is that depressive symptoms do not affect the oral normative condition.

\section{Methodology}

The methodology used was based on an inductive approach, with statistical procedures and descriptive technique using direct observation (Pereira et al., 2018). In this study, we evaluated the elderly population (aged 60 years or older) enrolled at CAISI (the Center for Integral Health of the Older Age), located in João Pessoa, Paraíba, Northeastern Brazil. This center covers an enrolled population of approximately 1000 seniors. We choose a convenience sample with participants of this center due to be a reference to clinical attendance and a meeting place for active elders in our region. To calculate the sample size inside this universe, we considered the prevalence of between 20 to $30 \%$ of depression in the older age (95\% of confidence level, sample error of 5\%, highest prevalence: 30\%) performed on an internet-web sample calculator (Santos, 2017) indicating 245 participants considering the higher value inside the interval correcting to finite sample. We included 250 elders in this study, for calculus convenience. The first 250 participants whose consent and fulfilled the inclusion criteria were selected for this study. The inclusion criteria for the study were: having a minimum age of 60 years and being registered at the care center above. Seniors who had cognitive deficits that could hinder or prevent the transmission of information on the variables studied were excluded. The screening of cognitive impairment was made by using the Portuguese version of the Mini-Mental State Examination (MMSE), translated and modified considering the cut-off points (19 and 25), according to the absence (illiterate) or presence of prior formal schooling, respectively. We considered participants with cognitive deficits who achieved a score $\leq 19$ as illiterate seniors, and those with scores $\leq 25$ as literate.

Data collection was carried out on a complete formulary, which is divided into a socioeconomic questionnaire addressing gender, age, family income, education, marital status, and medical records; data about DMFT (Decay, Missing, Filled Teeth), edentulism, and the use of and need for prosthesis and oral lesion; and GOHAI (Geriatric Oral Health Assessment Index), Pfeffer Scale, Katz Scale (both functional scales) and GDS-15 (Geriatric Depressive Scale). The GOHAI index was the simplified version with three options validated in Brazil with reliable association with the original scale (Hugo et al., 2012). The scores were classified into "excellent" (34 to 36 points), "regular" (30 to 33 points), and "bad" (<30 points) (Silva et al., 2005) and recategorized on favorable (excellent) and unfavorable (regular and bad perception) to binary statistical evaluation. Individuals 
were considered functionally independent when a score of five points or lower (Pfeffer Scale) (Sousa et al., 2013) was reached, and independent status was recognized when values over five points were reached (Katz Scale) (Pérez Cruz et al., 2014). The GDS-15 scale, validated in Brazil (Da Silva \& Valsecki-Júnior, 2000), comprises 15 dichotomous questions with five items exploring a positive attitude toward life and 10 negative items generically assessing dissatisfaction with life. A score greater than five is commonly considered as being indicative of suspected depression. Clinical examinations were performed by researchers after intra and inter-calibration with an oral pathology specialist (gold standard) (Kappa $\mathrm{p}<0.05$ ) for the verification of oral lesions on soft tissues mimicking the published criteria focusing on fundamental lesions (Saintrain et al., 2012). For the realization of other indexes, a previously trained and calibrated operator for the Brazil Oral Health National Survey conducted the examinations. The evaluation of the prostheses was performed based on the following criteria previously published (Almeida \& Almeida, 1999). The examination was performed at the dental office of the institution, using a No. 5 explorer, dental mirror, wooden spatulas, and personal protective equipment. A dental assistant performed the annotation of data regarding the clinical examinations.

The tabulation and data analysis were performed in $\operatorname{SPSS}^{\circledR}$ for Windows ${ }^{\circledR}$ version 13.0. Initially, descriptive analyses were made and a cross-tabulated analysis was conducted to assess the association between GDS-15, general characteristics, other scales, and normative oral conditions using the Chi-square and Fisher's exact test. A multivariate analysis was performed based on the method of binary regression using variables with values $<0.2$ on the univariate analysis. After the regression, the $\alpha$ significance level considered was 5\%. This research was conducted according to the ethical principles of research involving human participants, as stipulated by Resolution 196/96 of the National Health Council of the Ministry of Health of Brazil. Patients read and signed an informed consent that assured the respect of their autonomy, ensuring confidentiality, freedom to withdraw anytime, access to empirical material, and the presence of the researcher in the process or any time thereafter, and according to those dictated by the CFO resolution 179/91. The collection and analysis of data in this study were certified by the research ethics committee of the University Hospital (CAAE N 0788.0.000.126-11). All patients signed an Informed Consent Form.

\section{Results}

The mean age was 69 years ( 60 to 90 years, \pm 6.14 ). The elders were mostly females (77.6\%). Regarding marital status, $48.8 \%$ said they were married. The individuals evaluated had low education, being $26.4 \%$ of them illiterate. The average income was almost twice the minimum wage per family (US\$ 520.00), but the median was a minimum wage (US\$251.64), with the main source of income stemming from retirement (68\%). A large proportion (80.4\%) of individuals reported eating well (selfdeclared). Referred to medication, $52 \%$ did not report regular use. Of users, $27.2 \%$ used antihypertensive alone, $4.8 \%$ antihypertensive/oral hypoglycemiant drugs, $2.4 \%$ gastric cytoprotectors, and $2.4 \%$ calcium supplement. Only $1.6 \%$ used anxiolytic medications.

Concerning the dental variables shown in Table 1, the average DMFT was 28.26, with only 68 (27.2\%) elders having values below 25 . The missing component was the factor of greatest significance to this value, and 138 (55.2\%) were edentulous. The most prevalent type of denture used by the elders was the complete denture (64.4\% upper and $44.8 \%$ lower). One hundred and seventy-eight participants (71.2\%) needed to acquire or replace both the upper and the lower denture (complete, fixed, or removable). Of the 138 edentulous, 121 individuals made use of complete dentures on the upper arch and 106, on the inferior arch. Only 27 individuals with DMFT 28 did not need to replace any prosthesis. 
Table 1. Descriptive analysis of normative oral/dental conditions of the evaluated elderly population $(n=250)$.

\begin{tabular}{|c|c|c|c|}
\hline Normativ & e Oral Conditions & $\mathbf{n}$ & $\%$ \\
\hline Upper prosthesis & $\begin{array}{l}\text { Yes } \\
\text { No }\end{array}$ & $\begin{array}{c}195 \\
55\end{array}$ & $\begin{array}{l}78 \\
22\end{array}$ \\
\hline $\begin{array}{c}\text { Type of Upper } \\
\text { prosthesis }\end{array}$ & $\begin{array}{c}\text { Fixed } \\
\text { Removable Partial Denture } \\
\text { Complete Denture } \\
\text { Not applicable }\end{array}$ & $\begin{array}{c}5 \\
29 \\
161 \\
55\end{array}$ & $\begin{array}{c}2.0 \\
11.6 \\
64.4 \\
22.0\end{array}$ \\
\hline Lower prosthesis & $\begin{array}{l}\text { Yes } \\
\text { No }\end{array}$ & $\begin{array}{l}140 \\
110\end{array}$ & $\begin{array}{l}56.5 \\
43.5\end{array}$ \\
\hline $\begin{array}{c}\text { Type of Lower } \\
\text { prosthesis }\end{array}$ & $\begin{array}{c}\text { Fixed } \\
\text { Removable Partial Denture } \\
\text { Complete Denture } \\
\text { Not applicable }\end{array}$ & $\begin{array}{c}1 \\
27 \\
112 \\
110\end{array}$ & $\begin{array}{r}0.4 \\
10.8 \\
44.8 \\
44.0\end{array}$ \\
\hline Prosthesis needs & $\begin{array}{c}\text { Upper } \\
\text { Lower } \\
\text { Both arches } \\
\text { Not applicable }\end{array}$ & $\begin{array}{c}7 \\
19 \\
178 \\
46\end{array}$ & $\begin{array}{c}2.8 \\
7.6 \\
71.2 \\
18.4\end{array}$ \\
\hline DMFT $^{\mathrm{a}}$ & $\begin{array}{l}<25 \\
>25\end{array}$ & $\begin{array}{c}68 \\
182\end{array}$ & $\begin{array}{l}27.2 \\
72.8\end{array}$ \\
\hline Edentulism & $\begin{array}{l}\text { Yes } \\
\text { No }\end{array}$ & $\begin{array}{l}138 \\
112\end{array}$ & $\begin{array}{l}55.2 \\
44.8\end{array}$ \\
\hline Oral Lesions & $\begin{array}{l}\text { Yes } \\
\text { No }\end{array}$ & $\begin{array}{c}69 \\
181\end{array}$ & $\begin{array}{l}27.6 \\
72.4\end{array}$ \\
\hline
\end{tabular}

aDecayed, Missing, and Filled Teeth index. Source: Authors.

Oral lesions were detected in 69 individuals (26.7\% of the sample), 45 of them being edentulous. The most common clinical diagnostic hypotheses of lesions seen (no histopathologic procedures were performed and there was no radiographic confirmation of such hypotheses) were denture stomatitis, inflammatory fibrous hyperplasia, and nicotinic stomatitis. The GOHAI obtained values between 15 and 36 (maximum) with an average of 28.6 and a median of 29, giving an overall bad oral health perception. Regarding the GDS-15, almost a third of the population studied had depressive symptoms (33.2\%). GDS-15 had scores of 0 and 14 points and nobody reached the maximum score (15 points). In response to the question "Have you been feeling depressed in recent months?" (self-assessment of depression), 37.6\% answered yes, a very similar percentage when compared to the depression symptoms found by GDS-15 (Table 2). Table 3 shows the intersection between the general conditions of the elderly with GDS-15, checking significance by chi-square or Fisher's exact test ( $\mathrm{p}<0.05)$. 
Table 2. Descriptive analysis of oral and depressive self-perception, Katz and Pfeffer Scales ( $\mathrm{n}=250)$.

\begin{tabular}{|c|c|c|c|}
\hline \multicolumn{2}{|c|}{ Variables } & \multirow{2}{*}{$\begin{array}{l}\mathbf{n} \\
32\end{array}$} & \multirow{2}{*}{$\begin{array}{c}\% \\
12.8\end{array}$} \\
\hline GOHAI $^{\mathbf{a}}$ & Favorable & & \\
\hline (dichotomized) & Unfavorable & 218 & 87.2 \\
\hline \multirow{2}{*}{ GDS-15 } & Depressive symptoms & 83 & 33.2 \\
\hline & No depressive symptoms & 167 & 66.8 \\
\hline \multirow{3}{*}{$\begin{array}{c}\text { Depression } \\
\text { (Self-perception) }\end{array}$} & Yes & 94 & 37.6 \\
\hline & No & 155 & 62.0 \\
\hline & No response & 1 & 0.4 \\
\hline \multirow{2}{*}{ Pfeffer Scale } & Functional Dependence & 23 & 9.2 \\
\hline & Functional Independence & 227 & 90.8 \\
\hline \multirow{2}{*}{ Katz Scale $^{\mathrm{d}}$} & Partial Dependence & 7 & 2.8 \\
\hline & Independence & 243 & 97.2 \\
\hline
\end{tabular}

${ }^{a}$ Geriatric Oral Health Assessment Index ${ }^{19}$

${ }^{\mathrm{b}}$ Geriatric Depressive Scale ${ }^{12}$

${ }^{\mathrm{c}}$ Pfeffer Scale ${ }^{17}$

${ }^{\mathrm{d}}$ Katz Scale ${ }^{18}$

Source: Authors.

Table 3. Bivariate analysis between suspect of depression (GDS- $15^{\mathrm{a}}$ ) and general data/indexes data obtained from 250 elderly patients.

\begin{tabular}{|c|c|c|c|c|}
\hline \multirow{2}{*}{ Variables } & \multirow{2}{*}{ Categories } & \multicolumn{2}{|c|}{ Depressive Symptoms (GDS-15 ${ }^{\mathrm{a}}$ ) } & \multirow{2}{*}{$\mathbf{p}$} \\
\hline & & Yes $(\%)$ & No $(\%)$ & \\
\hline \multirow{2}{*}{ Gender } & Male & $10(17.9 \%)$ & $46(82.1 \%)$ & \multirow{2}{*}{0.060} \\
\hline & Female & $73(37.6 \%)$ & $121(62.4 \%)$ & \\
\hline \multirow{2}{*}{ Age (Years) } & 60 to 70 & $48(33.6 \%)$ & $95(66.4 \%)$ & \multirow{2}{*}{0.887} \\
\hline & Over 70 & $35(32.7 \%)$ & $72(67.3 \%)$ & \\
\hline \multirow{2}{*}{ Food Intake } & Good & $53(26.4 \%)$ & $148(73.6 \%)$ & \multirow{2}{*}{$<0.001$} \\
\hline & $\mathrm{Bad}$ & $30(61.2 \%)$ & $19(38.8 \%)$ & \\
\hline \multirow{2}{*}{ Use of Medications } & Yes & $44(36.7 \%)$ & $76(63.3 \%)$ & \multirow{2}{*}{0.263} \\
\hline & No & $39(30 \%)$ & $91(70 \%)$ & \\
\hline \multirow{2}{*}{ Marital Status } & Married & $37(30.3 \%)$ & $85(69.7 \%)$ & \multirow{2}{*}{0.346} \\
\hline & Non-Married & $46(35.9 \%)$ & $82(64.1 \%)$ & \\
\hline \multirow{2}{*}{ Schooling } & Illiterate & $30(45.5 \%)$ & $36(54.5 \%)$ & \multirow{2}{*}{0.014} \\
\hline & Educated & $53(28.8 \%)$ & $131(71.2 \%)$ & \\
\hline
\end{tabular}


Research, Society and Development, v. 10, n. 4, e1110413745, 2021

(CC BY 4.0) | ISSN 2525-3409 | DOI: http://dx.doi.org/10.33448/rsd-v10i4.13745

\begin{tabular}{|c|c|c|c|c|}
\hline \multirow{2}{*}{ Familial Income } & $\begin{array}{l}\text { Up to } 1 \text { minimum } \\
\text { wage }\end{array}$ & $49(34.8 \%)$ & $92(65.2 \%)$ & \multirow{2}{*}{0.659} \\
\hline & $\begin{array}{c}\text { Over one minimum } \\
\text { wage }\end{array}$ & $34(32.1 \%)$ & $72(67.9 \%)$ & \\
\hline \multirow{2}{*}{ Self-related depression } & Yes & $65(69.1 \%)$ & $29(30.9 \%)$ & \multirow{2}{*}{$<0.001$} \\
\hline & No & $18(11.6 \%)$ & $137(88.4 \%)$ & \\
\hline \multirow[t]{2}{*}{ GOHAI $^{b}$} & Favorable & $8(25 \%)$ & $24(75 \%)$ & \multirow{2}{*}{0.292} \\
\hline & Unfavorable & $75(34.4 \%)$ & $143(65.6 \%)$ & \\
\hline \multirow{2}{*}{ Pfeffer Scale } & $\begin{array}{l}\text { Functional } \\
\text { Dependence }\end{array}$ & $19(82.6 \%)$ & $4(17.4 \%)$ & \multirow{2}{*}{$<0.001 *$} \\
\hline & $\begin{array}{c}\text { Functional } \\
\text { Independence }\end{array}$ & $64(28.2 \%)$ & $163(71.8 \%)$ & \\
\hline \multirow[b]{2}{*}{ Katz Scale } & Partial Dependence & $6(85.7 \%)$ & $1(14.3 \%)$ & \multirow[b]{2}{*}{$0.006 *$} \\
\hline & Independence & $77(31.7 \%)$ & $166(68.3 \%)$ & \\
\hline
\end{tabular}

*Corresponding to two-sided Fisher's Exact Test

${ }^{a}$ Geriatric Depressive Scale (Simplified)

${ }^{\mathrm{b}}$ Geriatric Oral Health Assessment Index

Source: Authors.

It became clear that there was an association between depressive symptoms on GDS-15 and difficulties in food intake, illiterate condition, self-related depression, and the Katz and Pfeffer scales. Of normative oral conditions, no evaluated variables were associated with the GDS-15 scale (Table 4). In binary regression, excluding the functional scales and self-perception of depression to avoid co-linearity problems, we found that depressive symptomatology on GDS-15 was associated with difficulty in food intake $(\mathrm{p}<0.001)$, female gender $(\mathrm{p}=0.015)$, and illiterate condition $(\mathrm{p}=0.015)$ (Table 5). 
Table 4. Bivariate analysis between depressive symptoms (GDS-15ª) and normative oral conditions obtained from 250 elderly patients.

\begin{tabular}{|c|c|c|c|c|}
\hline \multirow[b]{2}{*}{ Variables } & \multirow[b]{2}{*}{ Categories } & \multicolumn{2}{|c|}{ Depressive Symptoms (GDS-15 ${ }^{\mathrm{a}}$ ) } & \multirow[b]{2}{*}{$\mathbf{p}$} \\
\hline & & & & \\
\hline \multirow{3}{*}{ Edentulism } & No & $32(28.6 \%)$ & $80(71.4 \%)$ & \multirow{3}{*}{0.162} \\
\hline & & & & \\
\hline & Yes & $51(37 \%)$ & $87(63 \%)$ & \\
\hline \multirow[b]{2}{*}{ DMFT $^{\mathbf{b}}$} & Up to 25 & $19(27.9 \%)$ & $49(72.1 \%)$ & \multirow[b]{2}{*}{0.280} \\
\hline & Over 25 & $64(35.2 \%)$ & $118(64.8 \%)$ & \\
\hline \multirow{3}{*}{ Lower prosthesis } & Yes & $44(31.4 \%)$ & $96(68.6 \%)$ & \multirow{3}{*}{0.502} \\
\hline & & & & \\
\hline & No & $39(35.5 \%)$ & $71(64.5 \%)$ & \\
\hline \multirow{3}{*}{ Upper prosthesis } & Yes & $61(31.5 \%)$ & $133(68.5 \%)$ & \multirow{3}{*}{0.256} \\
\hline & & & & \\
\hline & No & $23(39.7 \%)$ & $35(60.3 \%)$ & \\
\hline \multirow{3}{*}{ Prosthesis needs } & Yes & $7(35.2 \%)$ & $123(64.7 \%)$ & \multirow{3}{*}{$0.139 *$} \\
\hline & & & & \\
\hline & No & $11(23.9 \%)$ & $35(76.1 \%)$ & \\
\hline \multirow{3}{*}{ Oral Lesions } & Yes & $28(40.6 \%)$ & $41(59.4 \%)$ & \multirow{3}{*}{0.139} \\
\hline & & & & \\
\hline & No & $55(30.4 \%)$ & $126(69.9 \%)$ & \\
\hline
\end{tabular}

$* \mathrm{p}=0.167$ correspondings to two-sided Fisher's Exact Test

a Geriatric Depressive Scale (Simplified)

${ }^{\mathrm{b}}$ Decayed, Missing and Filled Teeth index

Source: Authors. 
Table 5. Binary Logistic Regression using GDS- $15^{\text {a }}$ scale as the dependent variable.

\begin{tabular}{|c|c|c|c|c|}
\hline Variables & Categories & $\mathbf{O R}^{\mathbf{b}}$ & $\begin{array}{c}\mathrm{CI} / 95 \%^{\mathrm{c}} \text { for } \\
\operatorname{EXP}(\mathbf{B})\end{array}$ & p-value \\
\hline \multirow{2}{*}{ Gender } & Female & 2.683 & \multirow{2}{*}{$1.214-5.927$} & \multirow{2}{*}{0.015} \\
\hline & Male & 1 & & \\
\hline \multirow{2}{*}{ Food Intake } & $\mathrm{Bad}$ & 3.944 & \multirow{2}{*}{$2.003-7.765$} & \multirow{2}{*}{$<0.001$} \\
\hline & Good & 1 & & \\
\hline \multirow{2}{*}{ Schooling } & Illiterate & 2.184 & \multirow{2}{*}{$1.162-4.103$} & \multirow{2}{*}{0.015} \\
\hline & Non-illiterate & 1 & & \\
\hline \multirow{2}{*}{ Edentulism } & Yes & 1.296 & \multirow{2}{*}{$0.725-2.318$} & \multirow{2}{*}{0.381} \\
\hline & No & 1 & & \\
\hline \multirow{2}{*}{ Prosthesis needs } & Yes & 1.392 & \multirow{2}{*}{$0.631-3.067$} & \multirow{2}{*}{0.413} \\
\hline & No & 1 & & \\
\hline \multirow{2}{*}{ Oral lesions } & Yes & 1.415 & \multirow{2}{*}{$0.758-2.643$} & \multirow{2}{*}{0.276} \\
\hline & No & 1 & & \\
\hline
\end{tabular}

${ }^{\text {a }}$ Geriatric Depressive Scale (Simplified)

b Odds ratio

${ }^{\mathrm{c}}$ Confidence Interval at 95\% level

Source: Authors.

\section{Discussion}

The data collection was performed in a specialized unit for elderly care and the results obviously cannot be generalized to all the elderly population. The profile of this sample showed a prevalence of females, young elders (60-70 years-old), and a poorly educated population, which is probably reflected in a worse quality of life and presence of comorbidities. An epidemiological approach in the same region in Brazil detached the same profile when evaluated depression symptoms and oral discomfort in elderly adults, highlighting that socioeconomic status and socialization may influence the presence and severity of depression but, more importantly, influences self-care including oral care (Saintrain et al., 2013). Another limitation of this study is the absence of objective measures of salivary flow to explain better the causality of tooth loss. Curiously, as previously showed, reduced salivary flow was not a determinant when depressive symptoms and untreated caries were evaluated together as shown in a Brazilian study (Sousa et al., 2013) but remain with explaining factor to periodontal disease and even edentulism (Ababneh et al., 2010).

Depression was suggested for $33.2 \%$ of the evaluated elders, using GDS-15. This result is very similar to previous analysis carried out in active community centers in Brazil (Oliveira et al., 2006) and our same region in Brazil (Saintrain et al., 2013). A German study showed the incidence of $36 \%$ of depression in the elderly population attended 138 primary care practices, focusing on a population over 75 years (Weyerer et al., 2013On In the other hand, institutionalized elders generally present higher evidence of depressive disease (Siqueira et al., 2009; Estrada et al., 2011). There was an association between depression and inappropriate food intake, low scholarship, self-related depression, and functional impairment on univariate analysis. On binary regression, female gender, illiterate condition, and inappropriate food intake were significantly associated with depressive symptoms. Previous studies supported the relationship between depression with female gender (Weyerer et al., 2013) and with a low level of education (Weyerer et al., 2013; Park et al., 2013). Curiously, intake of milk products, meat, fish, fowl, fruit, and vegetables was significantly lower in patients with depressive symptoms (Avila-Funes et al., 2006). GDS-15 scale evokes 
questions about self-perception associated with life dissatisfaction and even with dependence. In this study, functional dependence was associated with depression. A Mexican study using GDS-15 on an institutionalized population showed an association between depressive symptoms and difficulty performing the basic activities of daily living and instrumental activities of daily living (Avila-Funes et al., 2006). The natural physical limitations of the elderly, leading to dependence, are exacerbated by those limitations that society impinges on them, which are an outcome of social stereotypes and stigma (Oliveira et al., 2006). Depression could be associated in the elderly with mobility and visual impairment (Solis et al., 2014). Besides, physical and social activities are positively associated with lower levels of depression (Barcelos-Ferreira et al., 2013).

The normative oral conditions raised in this study revealed a well-established profile characterized by edentulism and difficulties with proper rehabilitation modeled by socioeconomic conditions. Corroborating these data, a previous analysis focusing on the impact of social impairment on oral condition showed that $85.9 \%$ of Brazilian seniors demonstrated a need for some oral treatment, $83.8 \%$ of the dentate subjects needed periodontal treatment and $57.3 \%$ of all seniors needed complete or partial prostheses. Social inequalities were also evident as Brazilians using free oral care services demonstrated a higher degree of need (Fonesca et al., 2015). Indeed, a cohort study with 1374 community-dwelling individuals showed that elderly individuals with a need for dental prostheses were significantly more likely to be prefrail and frail. Dentate elders had a lower chance of being frail than edentulous individuals (Andrade et al., 2013). Even bad oral self-perception could frequently be explained by the absence of teeth and socioeconomic condition. Confirming this assessment, a study showed that the physical domain of the WHOQOL-BREF scale, which measures the quality of life, was associated with the use of upper prosthesis and educational level. The psychological domain score was related to the level of education. The decayed, missing, and filled teeth (DMFT), gender, and educational level were associated with the social relation's domain. In the environment domain, an association with the use and need of a lower prosthesis, age, and educational level was observed (Fontanive et al., 2013; Oliveira et al., 2018).

Oral lesions were found in $26.7 \%$ of the evaluated elders, with soft tissue conditions being the most prevalent event. Moreover, ill-fitting or absence of hygiene of dentures caused many inflammatory/hyperplastic lesions. Unfortunately, these conditions are frequently found in this population, along with a lack of public policies concerning their oral health (Saintrain et al., 2012).

We observed that all normative dental conditions (edentulism, prosthesis needs, and use, DMFT, and oral lesions) were not statistically associated with depressive symptoms. These findings could indicate that depression was not associated with normative and rehabilitation conditions of oral health or in the elders in this evaluated population. Dental caries can occur at any age and periodontal disease is a progressive process even found in adults (Susin et al., 2005; Mendes et al., 2013). Tooth loss remains a dental health concern in the Brazilian population, even in younger individuals (Susin et al., 2007). Following this reasoning, a Chilean survey, for example, showed depression was associated with tooth loss during adult age but this relation disappeared on elders, focusing on different determinants of edentulism (Urzua et al., 2012). It has been suggested that depressive disorders in the elders might affect an individual's adaptive capacity to accept edentulism and wear dentures (Mendes et al., 2013). Depressive symptoms may act as determinants of caries treatment (Hugo et al., 2012; Skośkiewicz-Malinowska et al., 2018) but periodontal clinical parameters were not different between patients with major depression and control subjects as shown in a Brazilian study (Solis et al., 2014). Adding, a Jordanian study with 666 participants, with a large range of age, showed no differences between high susceptibility to depression individuals or not with periodontal parameters (Ababneh et al., 2010). However, other determinants could explain the poor normative dental condition in elderly individuals. Sometimes, financial constraints are the most commonly reported reason for not seeking treatment after tooth extraction, lack of time, and poor motivation, which may be attributed to the inability to overcome the emotional effect of losing their tooth (Okoje et al., 2012). In fact, the human ability to adapt physically and psychologically to changes in oral condition, and cope with these impacts when 
pain symptoms are absent, may act in addition to external factors like environment and social context (Teófilo \& Lelis, 2007). It is not necessarily associated with clinical depression.

Depressive symptoms did not modulate the self-perception condition of oral health. As shown previously, the strongest predictor of improvement in the total GOHAI score was the number of missing teeth, whereas the number of diseases was the strongest predictor of deterioration (Andrade et al., 2012). In our study, the huge majority of individuals reported unfavorable perception of their oral health different from previously shown in another study (Esmeriz et al., 2011). Curiously, this analysis showed educational and emotional aspects and geriatric depression are factors that influence the positive self-perception of oral health of elderly people (Esmeriz et al., 2011). However, well-being and depression reflect a very wide range of issues, and oral health seems to be important but not the only factor (Hassel et al., 2011). In our study, we dealt with a similar elderly population to another Brazilian region, where the population has other cultural determinants (Esmeriz et al., 2011). Some of the social conditions, nor only depressive status, most clearly associated with the perception of negative impact on the quality of life focusing oral health is female gender, poor education, and low income, immigrants or people belonging to minority ethnic groups (Cohen-Carneiro et al., 2011).

\section{Conclusion}

In this study, we observed a lack of association between depressive symptoms and normative oral conditions and oral self-perception in non-institutionalized elders in Northeastern Brazil confirming our hypothesis. These variables could be explained by different determinants including social, economic, and cultural features. Overall, we percept in this elderly population, despite depression symptoms, bad oral health, and unsatisfactory condition of rehabilitation by a dental prosthesis. On other hand, depression could lead to impairments on dental care search causing limitations on curative and restorative procedures (Oliveira et al., 2006; Choi et al., 2020).

Due to the increase in life expectancy of the population, the development of additional research focusing on the health determinants of elderly patients, especially oral health and its impact on systemic diseases and the quality of life of this aging population is advisable, since this information can be useful for guiding Health Public Policies and the practice of healthcare professionals.

\section{References}

Ababneh, K. T., Al Shaar, M. B. A., \& Taani, D. Q. (2010). Depressive symptoms in relation to periodontal health in a Jordanian sample. International Journal of Dental Hygiene, 8, 16-21.

Almeida, O. P., \& Almeida, S. A. (1999). Reliability of the Brazilian version of the ++ abbreviated form of the Geriatric Depression Scale (GDS) short form (in Portuguese). Arquivos de Neuro-psiquiatria, 57(2-B), 421-426.

Andrade, F. B., Lebrao, M. L., Ferreira Santos, J. L., \& Oliveira Duarte, Y. A. (2012). Correlates of change in self-perceived oral health among older adults in Brazil Findings from the Health, Well-Being and Aging Study. Journal of American Dental Association, 143(5), 488-495.

Andrade, F. B., Lebrão, M. L., Santos, J. L. F., \& Duarte, Y. A. O. (2013). Relationship between oral health and frailty in community-dwelling elderly individuals in Brazil. Journal of American Geriatrics Society, 61(5), 809-814.

Avila-Funes, J. A., Garant, M. P., \& Aguilar-Navarro, S. (2006). Relationship between determining factors for depressive symptoms and for dietary habits in older adults in Mexico. Revista Panamericana de Salud Publica, 19(5), 321-330.

Bakker, M. H., Vissink, A., Spoorenberg, S. L. W., Jager-Wittenaar, H., Wynia, K., \& Visser, A. (2018). Are Edentulousness, Oral Health Problems and Poor Health-Related Quality of Life Associated with Malnutrition in Community-Dwelling Elderly (Aged 75 Years and Over)? A Cross-Sectional Study. Nutrients, 10(12), 1965.

Barcelos-Ferreira, R., Yoshio Nakano, E., Steffens, D. C., \& Bottino, C. M. C. (2013). Quality of life and physical activity associated to lower prevalence of depression in community-dwelling elderly subjects from Sao Paulo. Journal of Affective Disorders, 150, 616-622.

Brennan, L. J., \& Strauss, J. (2014). Cognitive Impairment in Older Adults and Oral Health Considerations Treatment and Management. Dental Clinics of North America, 58(4), 815-828. 
Choi, K. H., Shin, S., Lee, E., \& Lee, S. W. (2020). Access to Dental Care and Depressive Illness: Results from the Korea National Health Nutrition Examination Survey. Medicina (Kaunas), 56(4), 189.

Cohen-Carneiro, F., Souza-Santos, R., \& Rebelo, M. A. B. (2011). Quality of life related to oral health: contribution from social factors. Ciência \& Saúde Coletiva, 16(Supl.1), 1007-1015.

Da Silva, S. R., \& Valsecki-Júnior, A. (2000). Evaluation of oral health conditions among the elderly in a Brazilian city. Revista Panamericana de Salud Pública, $8(4), 268-271$.

Eschweiler, G. W. (2017). Diagnostics and multimodal treatment of depression in old age: New developments. Zeitschrift fur Gerontologie und Geriatrie, 50(2), 99-105.

Esmeriz, C. E. C., Meneghim, M. C., \& Ambrosano, G. M. B. (2011). Self-perception of oral health in non-institutionalised elderly of Piracicaba city, Brazil. Gerodontology, 29(2), e281-9. 10.1111/ j.1741-2358.2011.00464.x.

Estrada, A., Cardona, D., Segura, A. M., Chavarriaga, L. M., Ordóñez, J., \& Osorio, J. J. (2011). Quality of life in institutionalized elderly people of Medellín. Biomedica, 31(4), 492-502.

Eulálio, M. C., Andrade, T. F., Melo, R. L. P., \& Neri, A. L. (2015). A estrutura latente da depressão em idosos: uma análise taxométrica. Cadernos de Saúde Pública, 31(3), 555-564.

Fonesca, F. A., Jones, K. M., Mendes, D. C., Dos Santos Neto, P. E., Ferreira, R. C., Pordeus, I. A., \& Barros Lima Martins, A. M. E. (2015). The oral health of seniors in Brazil: addressing the consequences of a historic lack of public health dentistry in an unequal society. Gerodontology, 32, $18-27$.

Fontanive, V., Abegg, C., Tsakos, G., \& Oliveira, M. (2013). The association between clinical oral health and general quality of life: a population-based study of individuals aged 50-74 in Southern Brazil. Community Dentistry Oral Epidemiology, 41(2), 154-162.

Forlani, C., Morri, M., Ferrari, B., Dalmonte, E., Menchetti, M., De Ronchi, D., \& Atti, A. R. (2014). Prevalence and gender differences in late-life depression: a population-based study. The American Journal of Geriatric Psychiatry, 22, 370-380.

Halpern, L. R. (2020). The Geriatric Syndrome and Oral Health: Navigating Oral Disease Treatment Strategies in the Elderly. Dental Clinics of North America, 64(1), 209-228.

Hassel, A. J., Danner, D., Schmitt, M., Nitschke, I., Rammelsberg, P., \& Wahl, H-W. (2011). Oral health-related quality of life is linked with subjective wellbeing and depression in early old age. Clinical Oral Investigation, 15(5), 691-697.

Hugo, F. N., Hilgert, J. B., de Sousa, M. D. L. R., \& Cury, J. A. (2012). Depressive symptoms and untreated dental caries in older independently living South Brazilians. Caries Research, 46, 376-384.

Hybels, C. F., Bennett, J. M., Landerman, L. R., Liang, J., Plassman, B. L., \& Wu, B. (2016). Trajectories of Depressive Symptoms and Oral Health Outcomes in a Community Sample of Older Adults. International Journal of Geriatric Psychiatry, 31(1), 83-91.

Kjellström, B., Gustafsson, A., Nordendal, E., Norhammar, A., Nygren, A., Näsman, P., Rydén, L., \& Åsberg, M. (2017). Symptoms of depression and their relation to myocardial infarction and periodontitis. European Journal of Cardiovascular Nursing, 16(6), 468-474.

Krausch-Hofmann, S., Bogaerts, K., Hofmann, M., de Almeida Mello, J., Fávaro, Moreira N. C, Lesaffre, E., Declerck, D., Declercq, A., \& Duyck, J. (2015). Missing Oral Health-Related Data in the interRAI-HC - Associations with Selected Variables of General Health and the Effect of Multiple Imputation on the Relationship between Oral and General Health. PLOS ONE, 10(12), e0146065. 10.1371 / journal.pone.0146065

Mendes, D. C., Silva, T. F., Barros, L. O., de Oliveira, M. V. M., Vieira, L. T., Haikal, D. S., Guimarães, A. L. S., \& De Paula, A. M. B. (2013). Analysis of the normative conditions of oral health, depression and serotonin-transporter-linked promoter region polymorphisms in an elderly population. Geriatrics \& Gerontology International, 13(1), 98-106.

Menezes-Silva, R., Oliveira, D. W. D., Biscaro, P. C. B., Orti, N. P., Sá-Pinto, A. C., \& Ramos-Jorge, M. L. (2016). Inquérito epidemiológico em população idosa (parte II): saúde bucal, ansiedade, depressão, estresse e uso de medicamentos. Scientia Medica, 26(1), 1-8.

Okoje, V. N., Dosumu, O. O., Alonge, T. O., \& Onyeaso, C. (2012). Tooth loss: are the patients prepared? Nigerian Journal of Clinical Practice, 15(2), 172175.

Okoro, C. A., Strine, T. W., Eke, P. I., Dhingra, S. S., \& Balluz, L. S. (2012). The association between depression and anxiety and use of oral health services and tooth loss. Community Dentistry and Oral Epidemiology, 40(2), 134-144.

Oliveira, D. A. A. P., Gomes, L., \& Oliveira, R. F. (2006). Prevalence of depression among the elderly population who frequent community centers. Saúde Pública, 40(4), 734-736.

Oliveira, M. B., Lopes, F. F., Rodrigues, V. P., Alves, C. M. C., \& Hugo, F. N. (2018). Association between socioeconomic factors, behavioral, general health and oral mucosa status in elderly. Ciência \& Saúde Coletiva, 23(11), 3663-3674.

Ouanounou, A. (2016). Xerostomia in the Geriatric Patient: Causes, Oral Manifestations, and Treatment. Compendium of Continuing Education in Dentistry, 37(5), 306-311.

Park, B., Park, J., \& Jun, J. K. (2013). Cognitive impairment, depression, comorbidity of the two and associated factors among the early sixties in a rural Korean community. PLoS ONE, 8(11), e79460. 10.1371 / journal.pone.0079460

Pereira, A. S., Shitsuka, D. M., Parreira, F. J., \& Shitsuka, R. (2018). Metodologia da Pesquisa Científica. UFSM. https://repositorio.ufsm.br/bitstream/handle/ 1/15824/Lic_Computacao_Metodologia-Pesquisa-Cientifica.pdf?sequence=1. 
Pérez Cruz, E., Lizárraga Sánchez, D. C., \& Martínez Esteves, M. D. R. (2014). Association between malnutrition and depression in elderly. Nutricion Hospitalaria, 29(4), 901-906.

Persson, G. R., Persson, R. E., MacEntee, C. I., Wyatt, C. C., Hollender, L. G., \& Kiyak, H. A. (2003). Periodontitis and perceived risk for periodontitis in elders with evidence of depression. Journal of Clinical Periodontology, 30(8), 691-696.

Révész, D., Verhoeven, J. E., Milaneschi, Y., de Geus, E. J., Wolkowitz, O. M., \& Penninx, B. W. (2014). Dysregulated physiological stress systems and accelerated cellular aging. Neurobiology of Aging, 35(6), 1422-1430.

Saintrain, M. V. L., Almeida, C. B., Naruse, T. M. O., \& Gonçalves, V. P (2012). Oral lesions in elderly patients of a community in Brazilian Northeast. Gerodontology.

Saintrain, M. V. L., Guimarães, A. V. P., Honório, V. A., de Almeida, P. C., \& Vieira, A. P. G. F. (2013). Depression symptoms and oral discomfort in elderly adults. Journal of the American Geriatrics Society, 61(4), 651-652.

Santos, G. Cálculo amostral: calculadora on-line. http://www.publicacoesdeturismo.com.br/calculoamostral

Seo, K., \& Kim, H. N. (2020). Effects of oral health programmes on xerostomia in community-dwelling elderly: A systematic review and meta-analysis. International Journal Dental Hygiene, 18(1), 52-61.

Sheikh, J. I., \& Yesavage, J. A. (1986). Geriatric Depression Scale (GDS): Recent evidence and development of a shorter version. Clinical Gerontologist, 5(12), 165-173.

Silva, D. D., Sousa, M. L. R., \& Wada, R. S. (2005). Self-perception and oral health conditions in an elderly population. Cadernos de Saúde Pública, 21(4), 1251-1259.

Siqueira, G. R., Vasconcelos, D. T., Duarte, G. C., Arruda, I. C., Silva da Costa, J. A., \& Cardoso, R.d. O. (2009). Analysis of depression in elderly living in the shelter "Christ the Redeemer", applying the Scale of Geriatric Depression (SGD). Ciência \& Saúde Coletiva, 14(1), $253-259$.

Skośkiewicz-Malinowska, K., Malicka, B., Ziętek, M., \& Kaczmarek, U. (2018). Oral health condition and occurrence of depression in the elderly. Medicine (Baltimore), 97(41), e12490. 10.1097 / MD.0000000000012490.

Solis, A. C. O., Marques, A. H., Pannuti, C. M., Lotufo, R. F., \& Lotufo-Neto, F. (2014). Evaluation of periodontitis in hospital outpatients with major depressive disorder. Journal of Periodontal Research, 49(1), 77-84.

Sousa, M. F. B., Santos, R. L., Arcoverde, C., Simões, P., Belfort, T., Adler, I., Leal, C., \& Dourado, M. C. N. (2013). Quality of life in dementia: the role of non-cognitive factors in the ratings of people with dementia and family caregivers. International Psychogeriatrics, 25(7), 1097-1105.

Susin, C., Valle, P., Oppermann, R. V., Haugejorden, O., \& Albandar, J. M. (2005). Occurrence and risk indicators of increased probing depth in an adult Brazilian population. Journal of Clinical Periodontology, 32, 123-9.

Susin, C., Haas, A. N., Opermann, R. V., \& Albandar, J. M. (2007). Tooth loss in a young population from south Brazil. Journal of Public Health Dentistry, $66(2), 110-115$

Teófilo, L. T., \& Leles, C. R. (2007). Patients' self-perceived impacts and prosthodontic needs at the time and after tooth loss. Brazilian Dental Journal,18(2), 91-96.

Tomioka, K., Okamoto, N., Kurumatani, N., \& Hosoi, H. (2015). Association of Psychosocial Conditions, Oral Health, and Dietary Variety with Intellectual Activity in Older Community-Dwelling Japanese Adults. PLoS ONE, 10(9), e0137656. 10.1371/ journal.pone.0137656

Urzua, I., Mendoza, C., Arteaga, O., Rodríguez, G., Cabello, R., Faleiros, S., Carvajal, P., Muñoz, A., Espinoza, I., Aranda, W., \& Gamonal, J. (2012). Dental caries prevalence and tooth loss in chilean adult population: first national dental examination survey. International Journal of Dentistry, 2012, 810170.10 .1155 / 2012/810170.

Warren, K. R., Postolache, T. T., Groer, M. E., Pinjari, O., Kelly, D. L., \& Reynolds, M. A. (2014). Role of chronic stress and depression in periodontal diseases. Periodontology 2000, 64(1), 127-138.

Weyerer, S., Eifflaender-Gorfer, S., Wiese, B., Luppa, M., Pentzek, M., Bickel, H., Bachmann, C., Scherer, M., Maier, W., \& Riedel-Heller, S. G. (2013). Incidence and predictors of depression in non-demented primary care attenders aged 75 years and older: results from a 3 -year follow-up study. Age and Ageing, 42(2), 173-180.

Yesavage, J. A., Brink, T. L., Rose, T. L., Lum, O., Huang, V., Adey, M., \& Leirer, V. O. (1983). Development and validation of a geriatric depression screening scale: a preliminary report. Journal of Psychiatric Research, 17(1), 37-49. 